\title{
An Experimental Analysis on the Moment Rotation of Beam-Column Connection using Cold-form Steel Section
}

\author{
Rahima Ummi Kulsum Nadya ${ }^{1 *}$, Fathoni Usman ${ }^{2}$ \\ ${ }^{1}$ College of Graduate Studies, Universiti Tenaga Nasional, 43000, Kajang, Selangor. \\ ${ }^{2}$ Institute of Infrastructure Energy, Universiti Tenaga Nasional, 43000, Kajang, Selangor. \\ *Corresponding Author E-mail: rahimaummi19@gmail.com
}

\begin{abstract}
A beam-column connection of cold-formed steel section was arranged as an isolated joint. An experimental testing has been done on the model specimen until the model reached its failure mode. The behaviour of the cold-formed bolted connection in the matter of its strength and stiffness of the steel connection was studied. In this study, gusset-plate and bolted angle flange cleat connection were used in which it can stiffen the cold-formed beam-column connection. Moment-rotation curves were generated from the test results to represent the behaviour of the bolted connections. The design expression of the beam-column connection is following the design standard of Eurocode 3 BS EN 1993-1-8. The set-up of the experimental analysis, the procedure and the failure mode results are discussed in details. The moment capacity of $5.9 \mathrm{kN} . \mathrm{m}$ has been recorded for the beam section and $7.3 \mathrm{kN} . \mathrm{m}$ for the column section. The stiffness $\left(\mathrm{S}_{\mathrm{j}}\right)$ was recorded as $120.94 \mathrm{kN} . \mathrm{m} / \mathrm{rad}$ for the beam section and $182.42 \mathrm{kN} . \mathrm{m} / \mathrm{rad}$ for the column section.
\end{abstract}

Keywords: beam-column connection, moment-rotation, cold-formed steel, gusset plate

\section{Introduction}

In building constructions practices, hot-rolled steel sections are frequently utilized as main structural frames and the cold-rolled or cold-formed steel sections are usually utilized as the secondary ones. [1]. The connection of a hot-rolled and cold-formed steel can be accomplished by using bolts and angle cleats. Nowadays, design expression on load bearing capacities using cold-formed bolted connection with respect to bearing failure are presented in several design recommendation, i.e., Eurocode 3 Part 1-3. However, the design expressions were presented according to specific testing data that might be different in material properties and dimension aspects. Although the semi-empirical expressions can be applied to cold-formed steel section with high ductility and design strengths of $280 \mathrm{~N} / \mathrm{mm}^{2}-350 \mathrm{~N} / \mathrm{mm}^{2}$, they might not be applicable for steel sections with high strengths but low in ductility. At present due to the development in technology, cold-formed steel sections that have a design strength up to $550 \mathrm{~N} / \mathrm{mm}^{2}$ are now applicable for building constructions [2].

Even though the cold-formed steel sections strength might be increased, the ductility of the steel was significantly reduced and this may cause an effect to the structural performance of section members. Very high values of local stresses and strains on the steel member joint may cause premature failure to the cold-formed steel structures. Gusset-plate connection are the most accessible type of connection for cold-rolled steel where the gusset-plate can be used as a connection for a beam-column members [3]. Gussetplate connections include a variety of shapes such as haunch gusset-plate and also rectangular gusset-plate where this type of gusset-plate have the advantages in terms of easy installation and maintenance.

The semi-rigid concept of a steel joint has been introduced for many years ago however until now, the beam-column joint of a steel structure are commonly designed by engineers in the presumptions that the steel joint are either considered as a pinned connection or as a rigid connection. Even though under these presumptions a more simplified structural analysis design for beamcolumn joints can be achieved, they also disregard the behaviour of the joint structure in the real situations. According to Daryan et al. as in [4], moment-resisting frame together with a rigid connections are commonly designed in beam-column steel structure. Meanwhile, in the other option was the cold-formed steel braced frame with semi rigid connection was being utilized. In terms of the uses of steel, the lateral load bearing system with the second combination was found to be more cost effective compared to the moment resisting system having rigid connection. The steel structures are more ductile than the braced frame with simple connections. Therefore, it can be considered as an enhanced system between the braced frame with simple connections and moment resisting frame with rigid connections.

In order to achieve the most accurate information on the physical behaviour of steel section connection, best practices were the experimental tests on a full-scale cold-formed structural frame. Therefore, the scope of this papers is to perform an experimental investigation to find the moment-rotation of bolted gusset plate connections for the cold-formed steel with $203 \mathrm{~mm}$ double Cchannel sections. The steel connections are known to give effect to the overall response of the structural frame and similarly, the behaviour of the frame also may give impact to the mechanical properties of the steel connection. Cantilever arrangement was used for this experimental design. 


\section{Test Specimen}

A lipped C-channel section of a lightweight cold-formed steel was manufactured and assembled as a beam-column connection steel frame. The grade and the thickness for each of the C-channel sections are $350 \mathrm{~N} / \mathrm{mm}^{2}$ and $3 \mathrm{~mm}$. Meanwhile, the depth of the channel is $203 \mathrm{~mm}$. The details for the C-channel sections are as in Fig. 1 and also Table 1 . To form an I-beam and I column, two of the lipped C-channel section were placed back to back and called as Double C-Channel sections with the length of $1000 \mathrm{~mm}$ for the beam sections and $1402 \mathrm{~mm}$ length for the column section. The model specimen was designed with a little tolerance to fit exactly on the test frame in the laboratory. For this study, all the fasteners that were utilized are non-preloaded bolts M16 Grade 8.8 and all bolt holes have been standardized into $17 \mathrm{~mm}$ in diameter to prevent any unexpected deformation due to large spaces in the bolt hole among the steel members. In this study, the connections were made using a haunch gusset plate and also bolted flange cleats. The experimental test specimen's data are compiled as in Table 2. .

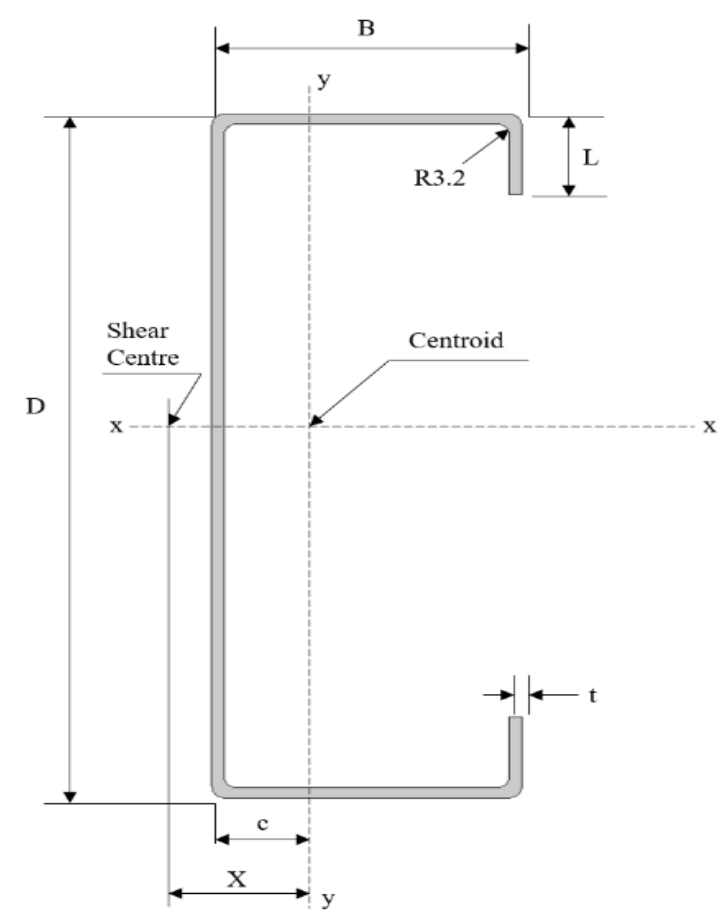

Fig. 1: Lipped C-channel

Table 1: Lipped channel - dimension and properties of the sections

\begin{tabular}{|c|c|c|c|c|c|c|}
\hline \multicolumn{4}{|c|}{ Nominal Dimension } & \multirow{2}{*}{ Section Area } & \multicolumn{2}{|c|}{ Mass } \\
\hline D & $\mathrm{B}$ & $\mathrm{L}$ & $\mathrm{t}$ & & Galv. & Black \\
\hline \multicolumn{4}{|c|}{$\mathrm{mm}$} & $\mathrm{mm} 2$ & \multicolumn{2}{|c|}{$\mathrm{kg} / \mathrm{m}$} \\
\hline 203 & 76 & 24 & 3.0 & 1140 & 9.07 & 8.95 \\
\hline \multicolumn{5}{|c|}{ Second Moment of Area } & \multicolumn{2}{|c|}{ Centroid, c } \\
\hline \multicolumn{2}{|c|}{ Ix } & & \multicolumn{2}{|c|}{ Iy } & & \\
\hline \multicolumn{5}{|c|}{$106 \mathrm{~mm} 4$} & \multicolumn{2}{|c|}{$\mathrm{mm}$} \\
\hline \multicolumn{2}{|c|}{7.1150} & & \multicolumn{2}{|c|}{0.8750} & \multicolumn{2}{|c|}{23.1} \\
\hline
\end{tabular}

\begin{tabular}{|c|c|c|c|c|c|}
\hline $\begin{array}{l}\text { Test } \\
\text { No. }\end{array}$ & $\begin{array}{l}\text { Size of } \\
\text { Beam }\end{array}$ & $\begin{array}{l}\text { Size of } \\
\text { Column }\end{array}$ & $\begin{array}{c}\text { Size of } \\
\text { Bolt }\end{array}$ & $\begin{array}{l}\text { No. of Bolt } \\
\text { at Beam } \\
\text { Connection }\end{array}$ & $\begin{array}{l}\text { No. of Bolt } \\
\text { at Column } \\
\text { Connection }\end{array}$ \\
\hline 1 & $\begin{array}{c}\text { Length, } \\
\mathrm{L}_{\mathrm{B}}= \\
1000 \\
\mathrm{~mm}\end{array}$ & $\begin{array}{c}\text { Length, } \\
\mathrm{L}_{\mathrm{C}}= \\
1402 \\
\mathrm{~mm}\end{array}$ & $\begin{array}{c}16 \mathrm{~mm} \\
\text { Grade } \\
8.8\end{array}$ & 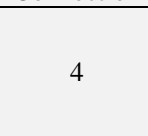 & 12 \\
\hline \multicolumn{6}{|c|}{$\begin{array}{l}\text { Note: } \\
\text { The dimension of beam and column are according to the manufacturer's } \\
\text { specification. Design steel grade }=350 \mathrm{~N} / \mathrm{mm} 2 \text {. } \\
\text { All bolts M16 Grade the } 8.8 \text {. Bolt size } d_{b}=16 \mathrm{~mm} \text {; Diameter of bolt hole } \\
d_{h}=d_{b}+1 \mathrm{~mm}=17 \mathrm{~mm} \text {. }\end{array}$} \\
\hline
\end{tabular}

\section{Method}

For this study, only one laboratory test was carried out. The method of the experimental testing was based on the previous study done by Tan et al. as in [5] The test was carried out using 30 $\mathrm{kN}$ self-reaction test frame as presented in Fig. 2. For the support, the top part of the column section was set-up as a pinned support, meanwhile, for the bottom part of the column section, it was setup as a fixed support. A bracing system was implemented to the top and bottom part of the beam-column specimen to restrict the movement. Due to the restriction in the laboratory, the load only can be applied manually using the jackscrew and the load was being applied on the end of the sections. A $100 \mathrm{kN}$ load cell recorded the load applied to the model specimen. Displacement transducer (LVDT) was being utilized in this experiment so that the moment-rotation of the model specimens can be determined. Five LVDT's named D1 to D5 were added to the arrangement to evaluate the displacement of each component during the testing; beam sections, column section and gusset plate section. The experimental setup for data collection layout is presented in Fig. 3. Data from the load cell and the displacement transducers were directly transferred into the computer via data logger. An increment of $0.1 \mathrm{kN}$ was used as the loading interval.

The loading was continuously being applied to the model specimen until there was a considerably large amount of deflection of the beam section being detected. During this time, the deflection of the beam members is given more effect to the applied load increments rather than the load itself. At this stage, an increment of $2 \mathrm{~mm}$ deflection was implemented. The experiment was run until the model specimen of beam-column cold-formed steel failed. The following criteria was considered to justify the failure of the model:

a. It is being observed that there was some substantial reduction in the applied load.

b. The beam was deflected significantly and the connections were deformed significantly.

c. Extreme deflection of the beam, i.e., the LVDT's limit was reached.

It is being expected that more than one failure modes may occur before the beam-column connection reach to the limit. Therefore, the failure mode was observed carefully along the analysis and the order of the failure mode was documented properly and compared with published reference [6]. Some deflection that might occur to the model specimen due to slipping during the beginning of the testing was excluded for easier comparison with the proposed specimen models.

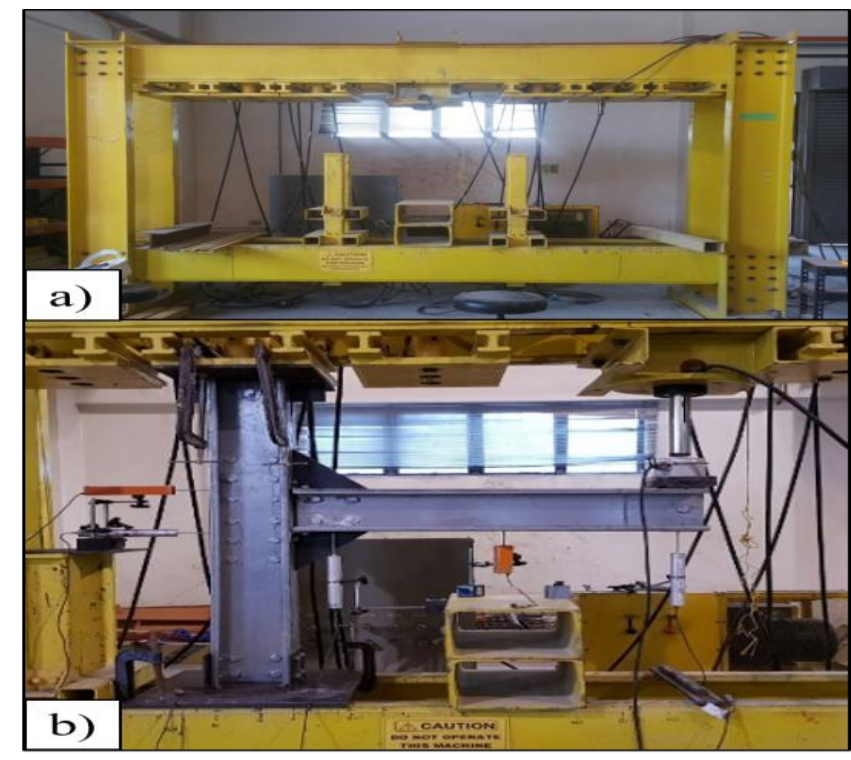

Fig. 2: An actual arrangement in the laboratory (before testing) 


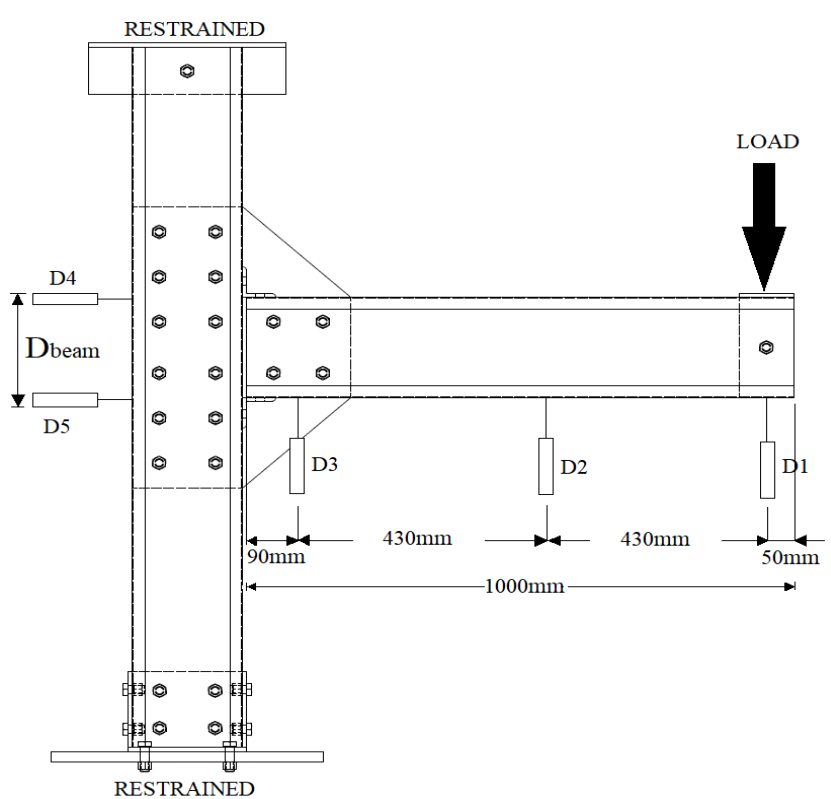

Fig. 3: Full-scale isolated joint test and data acquisition system

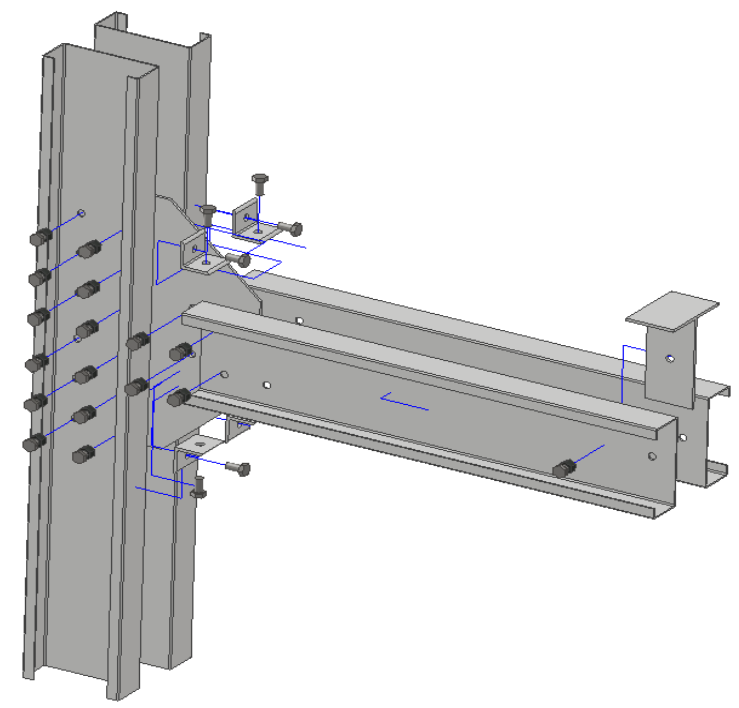

Fig. 4: The exploded view of the model

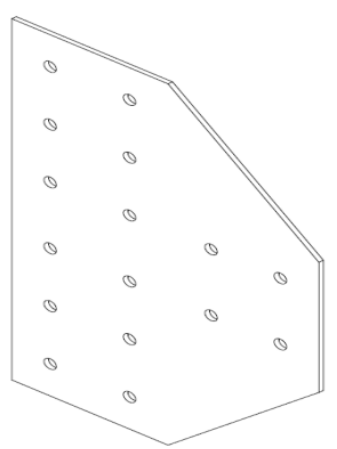

Fig. 5: The model of the gusset plate

\section{Results and Discussion}

At the beginning of the experiment, a slight deflection on the beam was observed and recorded. The deflection occurs due to weight incurred at the end of the beam by the load cell and cube. The isolated beam-column connection test was conducted until failure condition is obtained which may occur for a range of reasons such as yielding of angle-cleats, bending of beam flange and bending of column flange. For this study, the analysis was stopped due to some significant reduction in applied load were obtained. The modes of failure that happen in this experiment are explained in detail, aided by Fig. 6 below. At an early stage of the experimental testing progress, visible bending already occurred at the beam members. A significant large deflection was observed at the end of the beam. Based on the previous studies, the test was supposed to stop when the LVDT (D1) record exceeded the LVDT limit which in this case is $100 \mathrm{~mm}$. However, in this study, the test was stopped because the loading value was found to decrease even before the deflection at LVDT (D1) even reached $100 \mathrm{~mm}$. This is due to the specimen has reached the maximum lateral torsion. The stiff top angles pulled the column flange, while angles pushed into the column members, caused bending of the column flange. The compression zone of the column flange of the model was the most prone to failure. Buckling happened because high concentrated force from the bottom flange of the beam members pressed the flange of the column member. Even though there was bending to the column-beam connection structure, it was to be noted that there was no really any major visible defect occurred on the bolts, beam section, column section, gusset plate and also the angle flange.

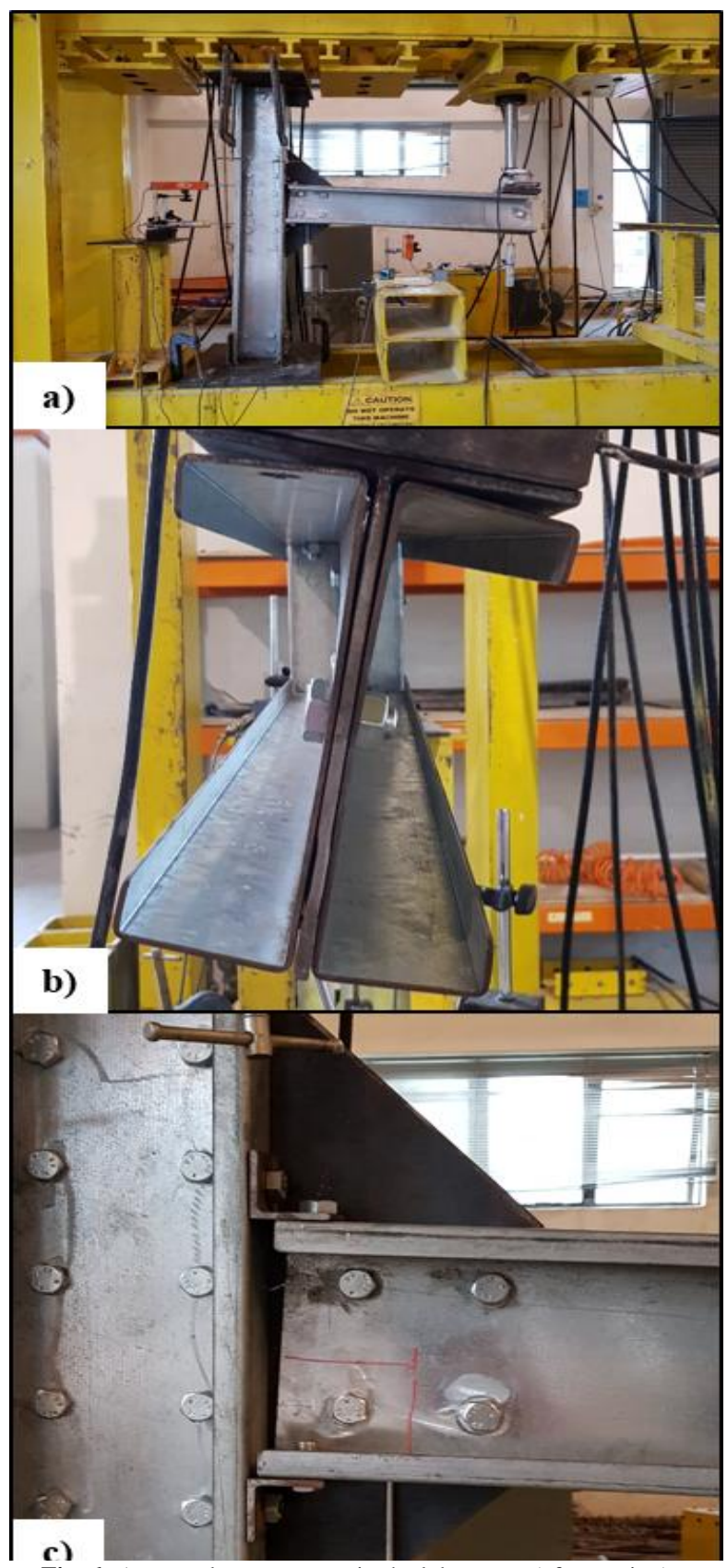

Fig. 6: An actual arrangement in the laboratory (after testing) 


\subsection{Failure Mode}

The maximum load recorded for the beam-column connection specimen was at $6.9 \mathrm{kN}$, where the model specimen failed and the failure mode was local buckling in the beam section of the steel structure. During the testing, the beam's failure mode happen first by the plastic bending at the end of the beam section caused by the tension zone of the connections. Meanwhile, the failure mode of the column occurred because of the plastic bending and the tensile zone followed by local buckling at the column web of the compressive area.

The failure mode of the beam-column specimen was progressive due to the excessive deformation of the compressive section. However, the defect on the bolts, beam and column section was not really noticeable. The experiment was terminated at the moment the specimen failed. Fig. 7 and Fig. 8 show the deformation versus load applied to each of the displacement transducers (LVDT). The LDVT results differ in two different graphs as D4 and D5 have a different direction than D1, D2 and D3.

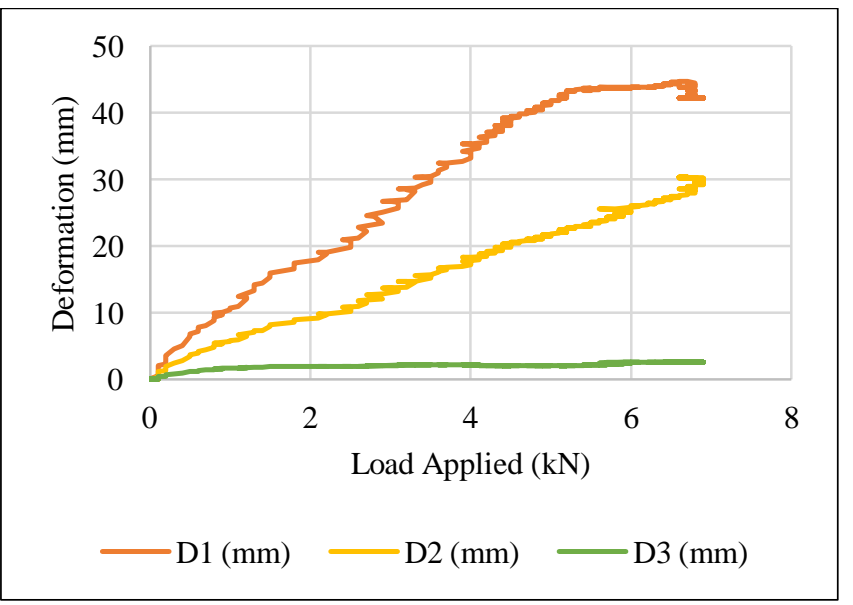

Fig. 7: Deformation of each (LVDT) vs Applied Load (D1, D2, D3)

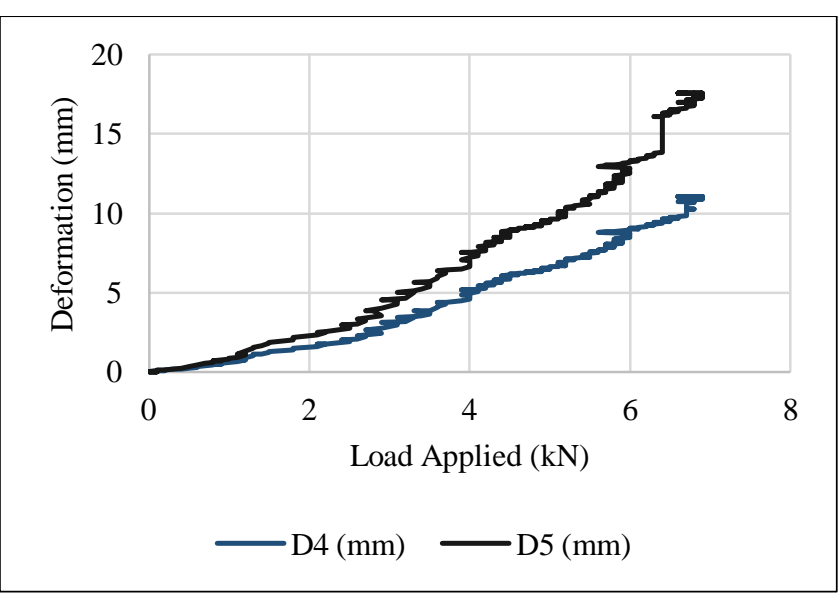

Fig. 8: Deformation of each (LVDT) vs Applied Load (D4 \& D5)

\subsection{Joint Stiffness}

Eurocode 3 BS EN 1993-1-8 [7] was utilized to calculate the moment capacity and stiffness of bolted beam-column connections. The theory of moment resistance and joint stiffness for coldformed steel sections that have been established in Eurocode 3 BS EN 1993-1-8. Equation (1) was used to calculate the shear resistance of the bolt, where the corresponding values of $\alpha_{v}$ and $\gamma_{M 2}$ are based on the Eurocode 3 .

$F v, R d=\frac{\alpha_{v} f_{u b} A}{\gamma M 2}$
According to Bučmys et al. as in [8], the mechanical model for beam-column gusset-plate connection utilized component method where the cold-formed steel sections were separated into three separate components, i.e., the beam, column and the gusset-plate (Fig. 9). An acting force, $F$ was generated at the end of the beam section as shown in Fig. 10. The calculation for the bending moment of the beam and column sections bolt groups are as follows; $M_{1}$ is for the beam section and bending moment $M_{2}$ are for the column section. The bolt groups for the beam and column sections were to be investigated separately than the gusset plate section as the bolt groups for beam and column are being affected by different bending moment as in Fig. 9: $M_{l}=F \cdot l_{l}$ for beam section and gusset plate; $M_{2}=F \cdot l_{2}$ for column section and gusset plate.

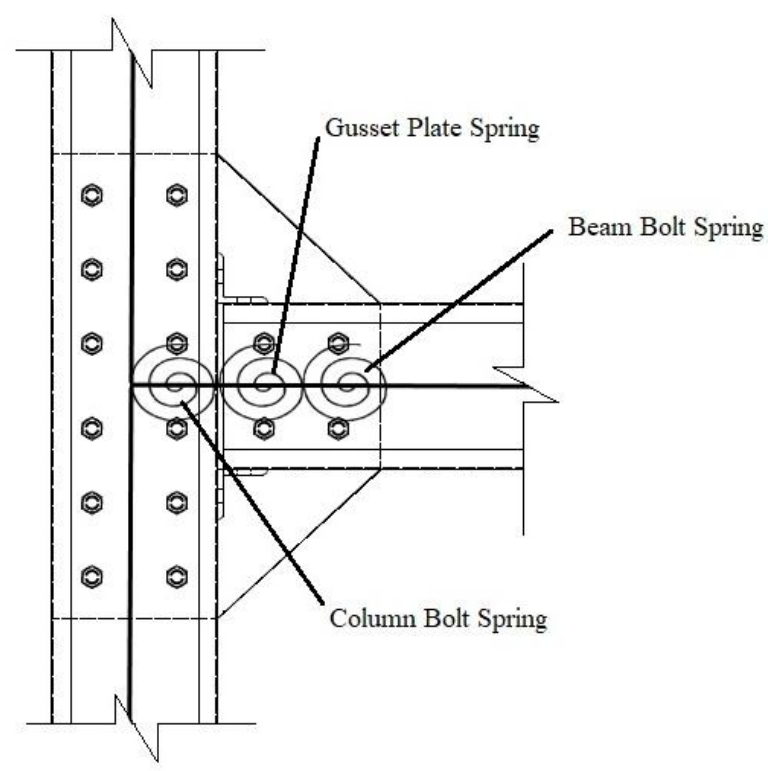

Fig. 9: A three spring model of the beam-column connection

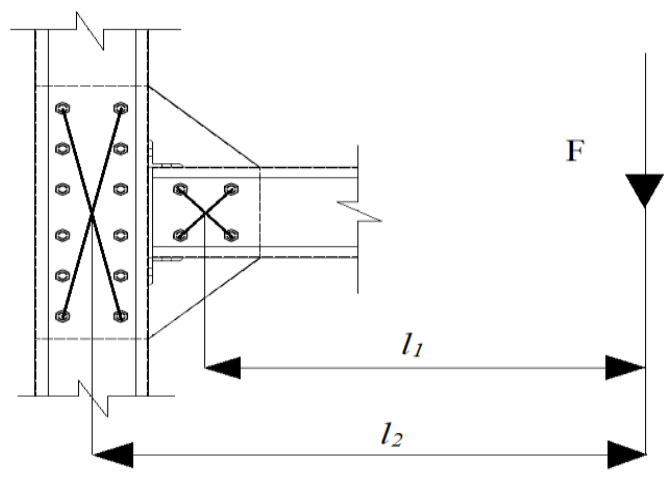

Fig. 10: A bending moment of model

According to Eurocode 3 Part 1-8 [7], the stiffness of a single bolt, $k_{b}$ is represented as in Equation (2).

$\frac{1}{k_{b}}=\sum \frac{1}{k_{i}}=\frac{1}{k_{12 a}}+\frac{1}{k_{12 b}}+\frac{1}{k_{11}}$

Every single bolt in a bolt group is affected by force $F_{b}$ that could be calculated from applied force. The relationship of force $F_{b}$ and deformation $\Delta_{b}$ is as in equation 3 :

$F_{b}=k_{b} \cdot E \cdot \Delta_{b}$

The stiffness of the bolt group, $S_{b, i n i}$ can be expressed as:

$S_{b, \text { ini }}=\frac{M}{\varphi}=\frac{E z_{b 1}^{2}}{\frac{1}{k b_{1}}}+\cdots+\frac{E z_{b n}^{2}}{\frac{1}{k b_{n}}}$ 
In order to calculate the stiffness of a gusset plate connection, Eurocode 3 Part 1-8 does not provide any specific recommendation. Thus, by referring to the formulation from study that have been done by Bučmys et al. as in [8] the rotation of the gusset plate $\varphi$ has consequently been derived as a sum of separate outstand element rotations $\varphi 1, \varphi 2, \varphi 3$ due to shear force $V$, bending moments $M_{1}$ and $M$ as in Fig. 10 resulting that the stiffness of a gusset plate, $S_{g p, i n i}$ can designed referring to the formula as in [8]:

$S_{g p, \text { ini }}=\frac{M}{\varphi}=\frac{M}{\varphi_{1}+\varphi_{2}+\varphi_{3}}=\frac{M}{\frac{M_{1} L_{a}}{E I_{1}}+\frac{V L_{a}^{2}}{2 E I_{1}}+\frac{L_{b}^{2} M}{2 L_{C} E I_{2}}}=\frac{M}{\frac{2 M_{1} L_{a}+V L_{a}^{2}}{2 E I_{1}}+\frac{L_{b}^{2} M}{2 L_{C} E I_{2}}}$

The rotation of joint of the beam-column cold-formed steel section, $\varphi_{j}$ is equal to the sum of the rotations obtained for the three springs:

$\varphi_{j}=\varphi_{g p}+\varphi_{b}+\varphi_{c}$

In this study, the strength and stiffness of the beam-column model are also affected by the design resistance and failure mode of a bolted angle that strengthen the beam-column model. Thus, the design resistance and failure mode of bolted angle flange cleat section together with its accompanying bolts should be done according to Eurocode 3 Part 1.8 [4] section 6.2.4. As a result, the overall initial stiffness of the joint, $S_{j, i n i}$ was calculated assembling the initial rotational stiffness of each spring using the formula below:

$S_{j, \text { ini }}=\frac{1}{\frac{1}{s_{g p, i n i}}+\frac{1}{s_{b, \text { ini }}}+\frac{1}{S_{c, \text { ini }}}+\frac{1}{s_{a f c, i n i}}}$

\subsection{Moment Rotation of Beam and Column Graph}

From some of the previous studies, extensive range of experimental testing and numerical simulations analysis for evaluating the behaviour of beam-column connections of cold-formed steel sections have been presented. Wong and Chung as in [9] performed beam-column connection testing with different arrangements of the bolted gusset-plate connections. The study was about the investigation of the effect of the thickness of gusset plate, the existence of the chamfer on the gusset plate and also each bolt distance on the strength and stiffness of the beam-column connection. Lateral restraints are being utilized for the beam and column structures. From the study, it was discovered that the shape of the gusset-plate plays a role in the behaviour of the beam-column connection. In the study by $\mathrm{Yu}$ et al. as in [10], they presented a semiempirical design method that can evaluate the rotational stiffness of the bolted gusset-plate connection. However, the technique that was presented was not very easy to use in common application because engineers need to predict the bearing deformation of the section web around the hole of the bolt first before applying the technique.

Sabbagh et al. [5, 6, 7] performed experimental and also numerical testing on the beam-to-column structure with gusset-plate connections. In the experiment, the beam-column connection was experiencing cyclic loads in order to consider the different stiffeners applied to the beam sections. Lateral restraints for a beam and the column structure were also being utilized in the study and as result, an optimum configuration of stiffeners for the model suggested was determined. The study by Ying-Lei et al. [14], focused on the in-plane behaviour of the beam-column connection using coldformed steel lipped channel section. The type of loading applied on the models are axial compression, major axis bending, axial compression with minor bending (compression) and also axial compression with minor bending (tension). From the study, it was concluded that the connection models undergo the axial compression with minor bending (tension) shows a more ductile behaviour compared to the other models that undergo other types of loading. Zeynalian et al. [15], performed experimental analysis to eighteen full-scale cold-formed steel truss connection whereby the model maximum load capacity and load-deformation behaviour were being analysed. Besides that, the failure mode on each of the truss connection also being studied. By comparing the experimental results with the design calculation according to the design standard whereby in this study AISI design standard was used, it was discovered that the truss connection capacities according to the design code are much lower than the actual capacities obtained by experimental analysis. Therefore, Zeynalian et al. concluded that the design code can be used as references but cannot be relied fully to obtain the accurate capacities for the cold-formed steel truss section.

The moment-rotation curve $(M-\Phi)$ can determine the behaviour of beam-column connection of the cold-formed steel sections [16]. The connection among the bending moment, $M$, that have been applied to the beam-column members and also the rotation, $\Phi$ between the connections represent the moment-rotation for the steel members. The bending moment acting on the beam-column connection can be calculated by multiplying the applied load with the distance between the point of load application and the face of the end-plate of the member. The rotation, $\Phi$ of the connected members is the rotation between the beam and the column axes. The rotation values can be obtained by performing laboratory testing. The rotation values are gathered by the utilization of displacement transducers, LVDTs during the laboratory experiment. Therefore, the moment-rotation curve $(M-\Phi)$ was drawn from the measured values of laboratory experiment as shown in Fig. 11. The following characteristics shown in Fig. 11 are obtained from the Eurocode 3 Part 1.8.

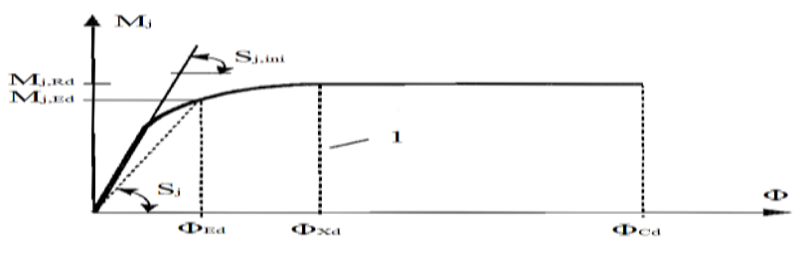

1 limit for $s$

Fig. 11: Design moment-rotation characteristic for a joint [7]

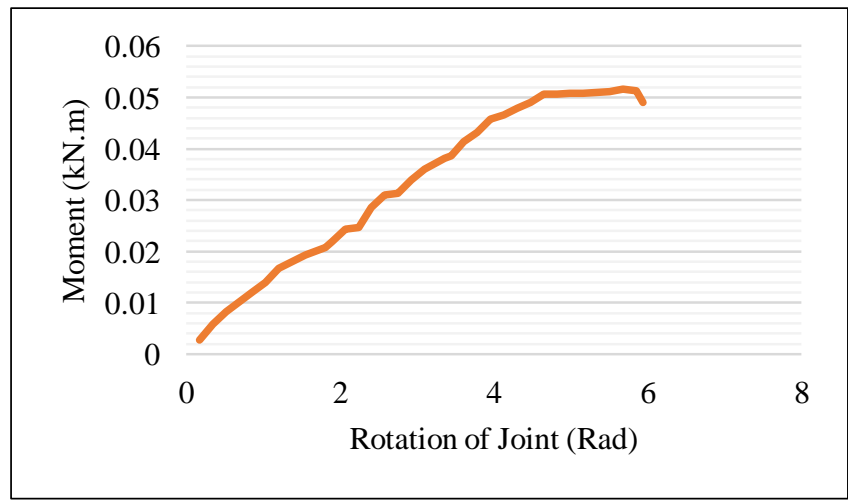

Fig. 12: Moment Rotation of Beam

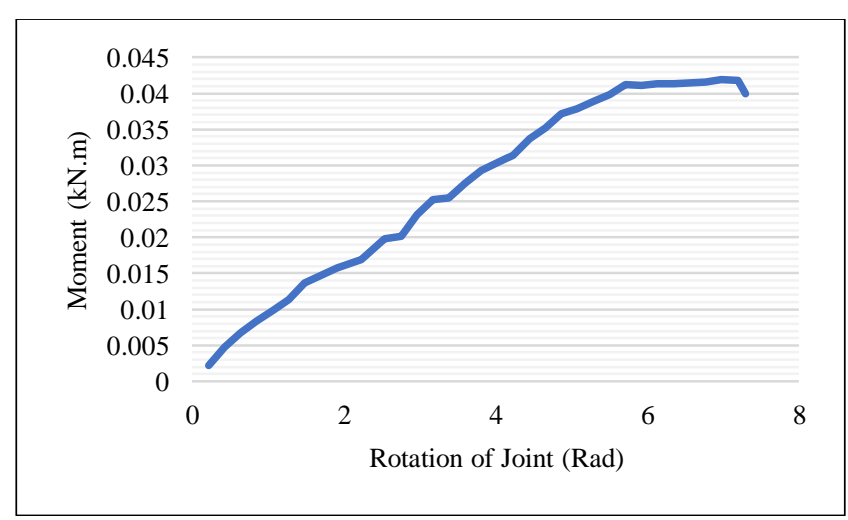

Fig. 13: Moment Rotation of Column 
The moment-rotation curves $(\mathrm{M}-\Phi)$ of the beam and column connections in this study presented in Fig. 12 and Fig. 13 are found to be non-linear. Since the large deformation in the tensile and compressive zones, ultimate rotation of the beam member was found to be higher than that of the column. The failure of the steel model depends on the placement of the load on the beam member and its properties.

Table 3: Strength and stiffness at $6.9 \mathrm{kN}$

\begin{tabular}{|c|c|c|c|c|c|}
\hline \multirow{2}{*}{ No. } & \multirow{2}{*}{ Connection } & \multicolumn{2}{|c|}{ Moment (kN.m) } & \multicolumn{2}{|c|}{$\begin{array}{c}\text { Stiffness } \\
(\mathrm{kN} . \mathrm{m} / \mathrm{rad})\end{array}$} \\
\cline { 3 - 6 } & & Beam & Column & Beam & Column \\
\hline 1. & $\begin{array}{c}6 \mathrm{~mm} \text { Gusset } \\
\text { Plate }\end{array}$ & 5.934 & 7.297 & 120.94 & 182.42 \\
\hline
\end{tabular}

The results were compared to the previous study by Aminuddin et al. [6]. The experimental test results from the studies are used as a reference wherein the study, beam-column connections were also being arrange as an isolated joint of cold-formed steel. The steel sections were analysed until its reach failure. However, the type of connection used in the previous study was only rectangular gusset. Whereby, in this study, a haunch gusset plate and angle flange cleat was used. The results from [6] were as in table 4 below.

Table 4: The strength and stiffness of the experimental test result in a previous study [6]

\begin{tabular}{|c|c|c|c|c|}
\hline No. & Connection & Load $(\mathrm{kN})$ & $\begin{array}{c}\text { Moment } \\
(\mathrm{kN} . \mathrm{m})\end{array}$ & $\begin{array}{c}\text { Stiffness, } \\
(\mathrm{kN} . \mathrm{m} / \mathrm{rad})\end{array}$ \\
\hline 1. & $\begin{array}{l}\text { Rectangular } \\
\text { Gusset Plate }\end{array}$ & 15.68 & 15.68 & 1948.06 \\
\hline
\end{tabular}

The comparison from this study and the previous study by Aminuddin et al. [6] shows that there were difference between the moment capacity and the joint stiffness value. This comparison might happen due to the different configuration of the bolt in this study and also previous study. The type of joint also can contribute to this differences. In the previous study, a rectangular gusset plate was used, whereas in this study a haunch gusset plate was used.

\section{Conclusion}

A laboratory analysis on full-scale isolated joint was conducted to assess the moment-rotation of cold-formed steel sections. The laboratory model failed due to the lateral torsion caused by the excessive deflection of the beam. The maximum moment of beam member model was found to be $5.934 \mathrm{kN}$ whereas the moment for the column member was 7.297. The stiffness of beam was found to be $120.94 \mathrm{kN} \cdot \mathrm{m} / \mathrm{rad}$ and that of the column was 182.42 $\mathrm{kN} . \mathrm{m} / \mathrm{rad}$. This study was limited to the number of joint configuration tested. Therefore, the joint behaviour of a wider range of bolted connection is recommended to be studied numerically.

\section{Acknowledgement}

This research was funded by Universiti Tenaga Nasional through the BOLD research grant (10289176/B/9/2017/52).

\section{References}

[1] K. F. Chung and K. H. Ip, "Finite element modeling of bolted connections between cold- formed steel strips and hot rolled steel plates under static shear loading," Eng. Struct., vol. 22, pp. 1271$1284,2000$.

[2] D. Dubină, V. Ungureanu, and R. Landolfo, Design of Cold-formed Steel Structures. 2012.

[3] Ž. Bučmys and A. Daniūnas, "Analytical and Experimental Investi Gati on of Cold-Formed Steel Beam-To-Column Bolte D GussetPlate Joints," J. Civ. Eng. Manag., vol. 21, no. 8, pp. 1061-1069, 2015 .
[4] A. S. Daryan, M. Sadri, H. Saberi, V. Saberi, and A. B. Moghadas, "Behavior of semi-rigid connections and semi-rigid frames," Struct. Des. TALL Spec. Build., vol. 23, no. 3, pp. 210-238, 2014.

[5] C. S. Tan and M. M. Tahir, "Laboratory Investigation of Bolted Angle Joints for Cold-formed Steel Double Channel Sections," vol. 2, no. c, pp. 14-17, 2015.

[6] K. M. Aminuddin, A. Saggaff, and M. M. Tahir, "Experimental behaviour of beam-column connection using cold-formed steel sections with rectangular gusset-plate," AIP Conf. Proc., vol. 1903, 2017.

[7] European Committee For Standardization, "BS EN 1993-1-8:2005 Eurocode 3: Design of steel structures - Part 1-8: Design of joints," Eurocode 3, vol. 8, no. 2005, p. 135, 2005.

[8] Ž. Bučmys, A. Daniūnas, J. P. Jaspart, and J. F. Demonceau, “A component method for cold-formed steel beam-to-column bolted gusset plate joints," Thin-Walled Struct., vol. 123, no. January, pp. 520-527, 2018.

[9] M. F. Wong and K. F. Chung, "Structural behaviour of bolted moment connections in cold-formed steel beam-column," vol. 58, pp. 253-274, 2002.

[10] W. K. Yu, K. F. Chung, and M. F. Wong, "Analysis of bolted moment connections in cold-formed steel beam - column subframes," J. Constr. Steel Res., vol. 61, pp. 1332-1352, 2005.

[11] A. Bagheri Sabbagh, M. Petkovski, K. Pilakoutas, and R. Mirghaderi, "Cyclic behaviour of bolted cold-formed steel moment connections: FE modelling including slip," J. Constr. Steel Res., vol. 80, pp. 100-108, 2013.

[12] A. Bagheri Sabbagh, M. Petkovski, K. Pilakoutas, and R. Mirghaderi, "Ductile moment-resisting frames using cold-formed steel sections: An analytical investigation," J. Constr. Steel Res., vol. 67, no. 4, pp. 634-646, 2011.

[13] A. Bagheri Sabbagh, M. Petkovski, K. Pilakoutas, and R. Mirghaderi, "Development of cold-formed steel elements for earthquake resistant moment frame buildings," Thin-Walled Struct., vol. 53, pp. 99-108, 2012.

[14] Y. L. Li, Y. Q. Li, Y. Y. Song, and Z. Y. Shen, "In-plane behavior of cold-formed thin-walled beam-columns with lipped channel section," Thin-Walled Struct., vol. 105, pp. 1-15, 2016.

[15] M. Zeynalian, A. Shelley, and H. R. Ronagh, "An experimental study into the capacity of cold-formed steel truss connections," $J$. Constr. Steel Res., vol. 127, pp. 176-186, 2016.

[16] C. Díaz, M. Victoria, P. Martí, and O. M. Querin, "FE model of beam-to-column extended end-plate joints," J. Constr. Steel Res., 2011. 